\title{
Arabic Learning Based on Language Laboratory to Improve Student Proficiency
}

\author{
Wahyudi Buska $^{1}$, Yogia Prihartini' ${ }^{2}$ Nurhasnah $^{3}$, M.Ridha, D.S. ${ }^{4}$ \\ ${ }_{1,2}$ Department of Arabic Language and Literature, Faculty of Civilization and Humanities \\ Sulthan Thaha Saifuddin State Islamic University of Jambi, Jambi, Indonesia, ${ }^{3}$ Department of Arabic \\ Education, Faculty of Tarbiyah and Teacher Training, State Islamic Institute (IAIN) of Bukittinggi, \\ Bukittinggi, Indonesia, ${ }^{4}$ Department of Arabic Education, Faculty of Tarbiyah and Teacher Training \\ State Islamic Institute (IAIN) of Kerinci, Kerinci, Indonesia \\ *wahyudi@uinjambi.ac.id
}

\begin{abstract}
This research is aimed; (a) to describe the spatial layout of Arabic language learning based on language laboratories, (b) to describe Arabic learning material using a Laboratory, (c) to describe the activities of lecturers and students in learning Arabic using a language laboratory, (d) to describe the monitoring and evaluation of laboratorybased Arabic learning at the University of Jambi. This research uses a descriptive method with quantitative and qualitative data. The sample of this study was students and lecturers from the Department of Arabic Language who took part in practicum lectures using language laboratories at the University of Jambi in the academic year 2018-2019 using purposive sampling techniques. Data collection techniques used are documentation, interviews, and questionnaires. The results of research findings are: 1). In the aspect of the utilization of the Language Laboratory of listening activities with the acquisition of a total score of 190 and produced a percentage of $47.5 \%$. If interpreted in Figure 4.17, the percentage of $47.5 \%$ is between the percentage of $40-60 \%$ and is included in a sufficient category. 2). In the aspect of utilizing the Language Laboratory for speaking activities with the acquisition of a total score reaching 286 and producing a percentage of $47.6 \%$. If interpreted in Figure 4.18, the percentage of $47.6 \%$ is between the percentage of $40-60 \%$ and is included in the sufficient category. It can be concluded that the motivation of students in listening to various Arabic news and talks is sufficient.
\end{abstract}

Keywords: Arabic Learning; Language Laboratory; Student Proficiency

\section{Introduction}

Language is an utterance, therefore language teaching must start by playing the sounds of the language in the form of words or sentences then pronounce them before reading and writing lessons [1]. Therefore language lessons must be filled with language activities not activities to learn the rules of language. language learning is not just knowledge but to be used in everyday life as a tool to communicate with other humans [2]. According to Ribeiro, et.al (2014, p. 34) language learning aims to achieve communicative skills in 4 skills, namely speaking, reading, listening and writing Of the four skills, listening is perhaps the most difficult skill to learn [3]. One problem that is often faced by the lack of or limited exposure of students to the language being studied. In teaching foreign languages, this problem is very pronounced. This is because exposure to students' daily lives is lacking, dependence on 
lecturers is very high [4]. However, often the exposure given by lecturers is limited because many foreign language lecturers are not speakers of the language; For example, sometimes the choice of words or pronunciation of lecturers is not appropriate according to the rules of the language being studied.

Therefore, in the world of education make various efforts so that the natural talents of these students can be developed and used properly through the process of language education. In carrying out the educational process supported by many elements that can optimize the educational process. One of them is in the form of educational media or learning media. Learning is a process to help students to learn well [5]. In teaching educators is a very important factor because educators can also be called the core of learning, good educators always try to use the most effective teaching methods and use the media / tools to achieve the learning goals that will be achieved [6].

In many countries, the use of language laboratories in foreign language learning has shown quite remarkable success [7]. Whereas in Indonesia the use of language laboratories is more than just the belief that language laboratories are sophisticated devices. Therefore, the use of a language laboratory is expected to provide better results than not using a language laboratory.

According to Konar, N. (2011, p.28), language laboratories are considered to play an important role in providing appropriate exposure for students, many universities in Indonesia provide language laboratories as an important facility in learning foreign languages, especially in learning to listen. In general, the condition of the language laboratory is in good condition [8]. Ajisafe, B., et.al. (2011: p.30) said good laboratory equipments, space and resources as inputs to effective language teaching and learning. The hardware and software available in the language laboratory are sufficient. As for the use of language laboratories, the ability of students has increased in understanding the material and capturing lessons easily [9]. While the obstacles that are often experienced are difficulties in operating equipment, some damaged headsets and lack of equipment of students (booth). Unfortunately, its utilization is not optimal. One reason is the lack of knowledge of lecturers on how to use language laboratories to support students' communicative skills. Sometimes teaching and learning activities in a language laboratory are limited to, audio playback, which is followed by answering questions related to the audio. In fact, language laboratories have great potential to support good and effective language teaching.

The laboratory has an important role in the process of teaching and learning foreign languages. First, language laboratories offer language learning with several possible benefits such as listening, writing, speaking and copying the native speech model. Another reason for the advantages of language laboratories is that learning foreign languages is very important for learners to not only understand the language mentally, but learners also gain practice, especially in large classes where it is difficult for a lecturer to give each learner practice adequately and control his accuracy. The existence of a language laboratory will be very helpful because of the availability of facilities for individual practice, accurate models and error correction [10].

In improving Arabic language studies at Jambi University there are several issues that should be considered. These problems include curriculum, teacher performance, learning process, teaching materials, teaching methods and techniques, learning facilities, motivation, and so forth. In this issue, the role of lecturers must be further enhanced so that Arabic lessons become subjects favored by students.

A lecturer must be able to provide encouragement or motivation to students so that students are more interested in learning Arabic. In addition, lecturers should teach students by using varied and interesting ways, or techniques so that learning activities in Arabic are not 
boring. More importantly, the lecturer must teach all the basic competencies required by the curriculum. The basic competencies in question are listening, speaking, reading and writing [11].

The success of teaching is very determined when teaching is able to change students [12]. This change in the sense of being able to develop and develop the potentials of the students so that students can benefit directly in their personal development [13]-[14] To create Arabic learning, laboratory and learning media are needed to support the creation of creative and innovative Arabic learning.

Thus the media is a component of learning resources or physical vehicles that contain instructional material in the student environment that can stimulate students to learn [15]. Expected to be Active, Creative, Effective and Enjoyable Learning. However, the current obstacle is the lack of time to carry out practical work in the language laboratory because time has been widely used to complete the material.

Therefore, lecturers need to design Arabic learning that uses laboratories, meaning that concept learning is done in conjunction with practicum activities in the laboratory [16]. Arabic learning is carried out in the laboratory not only asking students to listen to what is conveyed by the lecturer, but students will practice learning more freely and directed. Students can use the facilities available in the laboratory such as microphones, LCDs, learning media, etc [17]. So students can practice speaking, listening, and also writing.

Laboratory-based learning is a learning strategy that allows students to empirically practice cognitive, affective, psychomotor abilities using laboratory facilities . Laboratories are workplaces or practices for performance or conducting experiments or experiments in the form of virtual and virtual places. Laboratories can be in the form of workshops, hospitals, studios, marine, markets, hotels, offices, factories, and others. The language laboratory is a tool to train students to hear and speak a foreign language by presenting pre-prepared lesson materials. The media used are recording devices. By using the language laboratory the lecturer can also utilize his ability to facilitate students to be actively involved in the communication process through headsets and microphones available in their respective study desks [18].

The language laboratory is also a tool to train students to hear and speak a foreign language by presenting the material of the lesson previously delivered [19]. The laboratory used at the University of Jambi is a multimedia language laboratory, called the multimedia language laboratory because the laboratory at the university not only uses audio media but audio-visual is also used.

A multimedia language laboratory is a set of audio and video electronic equipment consisting of instructor consoles as the main machine, equipped with repeaturlanguage learning machines, tape recorders, DVD players, video monitors, headsets and student booth [20]. In Arabic courses, opportunities for writing, reading, listening and speaking activities need to be provided with facilities and an atmosphere that supports learning. Supporting facilities are provided in a language laboratory

Based on the description above, the researcher will conduct research on learning Arabic using a language laboratory at the University of Jambi. The objectives to be achieved in this study are (a) To describe the spatial layout of Arabic language learning based on language laboratories at the University of Jambi. (b) to describe the process of teaching and learning Arabic using a laboratory at Jambi University. (c) to describe the activities of lecturers and students in learning Arabic using a language laboratory at the University of Jambi. (d) to describe the monitoring and evaluation of Laboratory-based Arabic learning at the University of Jambi. 


\section{Method}

This research generally aims to describe Arabic Learning using a language laboratory to improve language competence at the University of Jambi. Therefore, this type of research uses descriptive qualitative research. qualitative descriptive is a research design that describes variables or conditions as they are in a situation [21]. While the purpose of qualitative descriptive is to make a description, a systematic, factual, and accurate description of the facts, traits, and relationships between the phenomena under study, therefore this study uses a descriptive type of research that is research that aims to describe the events that occur in present time. The description of the event was carried out systematically and put more emphasis on factual data.

This research is qualitative research with descriptive method. Qualitative research is research that uses a natural setting, with the intention of interpreting phenomena that occur and is carried out by involving various existing methods [22]. The research method is a method used by researchers in collecting research data. The method used in this research is descriptive method. This method has been used, the use of qualitative descriptive methods in this study intended to describe or describe data relating to the use of language laboratories in learning Arabic at the University of Jambi.

Descriptive research is research that is intended to gather information about the status of symptoms that exist, namely the state of symptoms as they were at the time the study was conducted [23]. Data collected in the form of data from observations, namely regarding the condition of language laboratories, the use of language laboratories in teaching Arabic, the effectiveness of the use of language laboratories for students in teaching Arabic, and the factors that support and that inhibit the use of language laboratories in language teaching Arabic at Jambi University.

The data in this study are the use of language laboratories in learning Arabic at the University of Jambi whose data were taken from observations and interviews. The data source in this study is a lecturer in Arabic studies at the University of Jambi. Data collection procedures are the most strategic step in research, because the main purpose of the research is to obtain data. Without knowing data collection techniques, the researcher will not get data that meet the established data standards. Data collection procedures in this study; (1) Observation; (2) Interview; (3) Tests; (4) Questionnaire.

The main informants in this study were three Arabic language lecturers and there were three representative students of each class as well as leaders, department heads, department secretaries. In this research, the method used is participation observation, in-depth interviews, and document analysis [24]. To present data so that it is easy to understand, the data analysis steps used in this study are Analysis Interactive models from Miles and Huberman, which divide the steps in data analysis activities with several parts, namely data collection (data collection), data reduction (data reduction), data presentation (data display), and drawing conclusions or verification (conclusions) [25].

The validity of the data in this study was also carried out by triangulation. Researchers will use triangulation of data sources and techniques. Triangulation of data sources includes the data of Arabic lecturers, head of the labor and students. Technical triangulation includes indepth interviews, observation and documentation studies. In this test it is expected to obtain data that are truly valid 


\section{Result and Discussion}

The findings of research on learning Arabic using the Language Laboratory at the University of Jambi (UNJA); The Integrated Development Unit (UPT) of the Language Laboratory of the University of Jambi has excellent programs, namely: through developing a language laboratory into a self-access learning center (SALC), a language laboratory equipped with independent learning resources that enable students to learn on their own/independent without teachers. The learning objectives and targets in the Language Development Unit (UPB) at the University of Jambi include; 1). Practice speaking and communication skills in the language concerned. 2). Deepening language knowledge in a broader scope in a variety of objectives. 3). Improve students' Arabic pronunciations..

\section{A. The Use of Language Laboratories in Learning Arabic at the University of Jambi}

Learning functions in the language laboratory owned by the University of Jambi include 1) Conversation function: this language lab function can train students accustomed to conversing with other students or with teachers. The function of the language laboratory at the University of Jambi can familiarize students with the Arabic language in daily life, 2) Listening function: This language laboratory function trains students to listen to Arabic conversation and also accustoms the students to fluently listen to conversations with foreigners from the middle east, european and asian countries, 3). instructor management function: This language laboratory function makes it easy for teachers to organize a class, in this language laboratory function the instructor will easily provide questions and questions or talk with students having the mechanical buttons of the existing language laboratory.

The spatial planning of learning Arabic using a language laboratory at the University of Jambi was created with attention to the needs of students. A comfortable atmosphere is created by installing an Air Conditioner (AC) and the sound system in the upper corner of the room. Tables and chairs are set with U-formation and each table is equipped with a headset for learning listening.

Arabic learning materials using laboratories at the University of Jambi consist of speaking and listening material, while the other two reading and writing materials are given in different classes. Storytelling or retelling material is material that is considered difficult for students. Submission of material is done through demonstration methods and various media such as film, LCD, and also tape recorders.

Lecturers and students are active in conducting laboratory-based Arabic learning at the University Jambi. Lecturers prepare to learn activities ranging from Semester Lecture Plans (RPS), laboratory use permits, to preparing laboratory equipment. Motivation is given by lecturers in the form of coaching, giving rewards and punishment. Through the incorporation of various methods, lecturers are able to activate students such as listening, speaking, discussion, and debate activities. Students are given the opportunity to compete through loud reading activities and also storytelling.

Monitoring and evaluation of laboratory-based Arabic learning at Jambi University is carried out during the learning process. The lecturer monitors every development shown by students. Evaluation activities are carried out in the form of written, oral, and practical tests to determine students' listening and speaking skills. Students who have good achievements will receive a reward and enter the enrichment program. 


\section{B. Increased Proficiency in Arabic Language Students in using the Language laboratory at the University Jambi}

- Aspects of Utilization of Language Laboratories for listening activities. In the aspect of the utilization of the Language Laboratory of listening activities with the acquisition of a total score of 190 and produced a percentage of $47.5 \%$. If interpreted in Figure 4.17, the percentage of $47.5 \%$ is between the percentage of $40-60 \%$ and is included in a sufficient category. It can be concluded that the motivation of students listening to various news and Arabic language talks is already quite strong.

- Aspects of Utilization of Language Laboratories for speaking activities. In the aspect of utilizing the Language Laboratory for speaking activities with the acquisition of a total score reaching 286 and producing a percentage of $47.6 \%$. If interpreted in Figure 4.18, the percentage of $47.6 \%$ is between the percentage of $40-60 \%$ and is included in the sufficient category. It can be concluded that the motivation of students in listening to various Arabic news and talks is sufficient.

C. The successful use of the Language Laboratory in Improving Arabic Language Proficiency at the University of Jambi

The results of research findings on the success of language laboratories in improving Arabic language proficiency at the University of Jambi, That the language laboratory at the University of Jambi is a laboratory-created to facilitate the delivery of language material in a room, like the language laboratory owned by the University of Jambi whose function is to support the success of the ability of students to absorb language material, both foreign languages especially Arabic. The utilization of language laboratories by Arabic language lecturers has been utilized quite well because Arabic lecturers at the University of Jambi mostly have used language laboratories even though in different ways. Lecturers who use for all Arabic learning materials and there are some lecturers utilize language laboratories only for certain Arabic materials.

There is an effort to improve the effectiveness of the management of language laboratories through the development of language laboratories into self-access learning centers (SALC), namely language laboratories equipped with independent learning resources that enable students to be able to learn on their own without teaching. To develop a language laboratory into a language laboratory that also functions as a self-access learning center, if the laboratory room allows it means that if there is room left, the campus can simply add a number of hardware and software as a means of independent learning into the laboratory with or without rearranging devices existing laboratories. In a simple form, the campus simply needs to add a number of independent learning resources, namely cassettes, books, dictionaries, and other reading materials stored on shelves/cabinets that students can borrow and then use them to learn. In the most sophisticated form of the Jambi University language laboratory, language laboratories plus a variety of complete hardware such as cassettes, CDs, VCDs and DVD players, TVs, multimedia computers, and various software including cassette tapes, CDs, VCDs, DVDs, kits self study, reference books and stories, and access to learning resource links available on the internet.

The use of language laboratories is emphasized more by the lecturer on the aspect of listening and speaking skills so that learning materials taught to students are always related to the ability aspect so that the use of language laboratories can be utilized to the maximum not only moving the room from class to moving to the language laboratory but at when implementing learning in a language laboratory, lecturers make maximum use of it and the expected high learning outcomes will be achieved. 
In the use of language laboratories by looking at learning material and aspects of ability, most lecturers utilize language laboratories in the aspect of listening and speaking abilities, but there are also lecturers who use language laboratories in every Arabic language learning by utilizing language laboratories for all learning materials, and for all aspects Good listening skills, speaking, reading and writing and language laboratories are used for all abilities both language skills and literary abilities. In addition to utilizing Arabic language laboratories, lecturers also utilize audiovisual laboratories in learning Arabic.

The implementation of learning in Arabic language laboratories there are several lecturers who use Arabic language special laboratories and there are also lecturers who use audiovisual laboratories. The equipment used for teaching and learning activities in language laboratories, especially in the ability to listen and speak is more audio. Hearing aids (audio) that are used consist of, computers/laptops, mater units, the headset of lecturers and students, speakers, and additional equipment in the form of LCD and blackboard. The equipment is always used in the implementation of learning in the language laboratory at the University of Jambi. The implementation of learning in language laboratories if adapted to the learning material, the use of language laboratories can be used optimally. Thus, this shows that Arabic lecturers at the University of Jambi have been trained, and has the skills and abilities in selecting and using audiovisual learning media in language laboratories because teaching media is one of the supporting factors which indirectly influences the success of a learning Arabic in the University of Jambi language learning unit.

\section{Conclusion}

Based on the results of the research and discussion, the conclusions of this research are (a) Spatial planning of learning Arabic using a language laboratory at the University of Jambi is made by considering the needs of students. Air conditioning (AC) and the sound system in the upper corner of the room. Each table was equipped with a headset for the learning of listening and speaking. (b) Teaching Arabic at Jambi University has used a multimedia language laboratory as a medium for learning. It includes a home theater, hearing aids such as video, film, tape recorder, television and satellite dish, and wireless mic clip. Explanation of the material is done through demonstration methods and various media (c) Lecturers and students are active in learning Arabic using a language laboratory at the University Jambi. Through the incorporation of various methods, lecturers are able to activate students such as listening, speaking, discussion, and debate activities. Students are given the opportunity to compete through reading activities and also storytelling. (d) Monitoring and evaluation of Arabic learning using a language laboratory at the University of Jambi are carried out throughout the learning process. Evaluation activities are carried out in the form of written, oral, and practical tests to determine students' listening and speaking skills. After students listen to Arabic material carefully, then students are asked to understand, imitate, and conduct a dialogue between lecturers and students as well as between students. The dialogues exhibited by students went smoothly. In addition to this, students are also heard and shown films or videos in Arabic, then the lecturer asks students to retell using Arabic.. 


\section{Acknowledgment}

I would like to express my sincere thanks to all the speakers at the 2019 Bukittinggi International Conference on Education (BICED): H. Ramlan Nurmatias, SH. (Mayor of Bukittinggi, Indonesia), Prof. Dr. Rohaida Mohd Saat (Dean Faculty of Education Universty of Malaya, Malaysia), Dr Noor Azam OKMB Haji-Othman, MA. (Dean Faculty of Education University Brunai Darussalam), Assoc. Prof. Dr. Iswantir M, M.Ag (Deputy Dean Faculty of Education and Teaching IAIN Bukittinggi, Indonesia), Assoc. Pof. Dr. Ekkarin Sungtong (Dean Faculty of Education Princes of Songkla University, Thailand) who has shared knowledge, information, and latest findings in their respective fields of science. I wish to express my sincere gratitude to the Person in Charge and all committee of BICED for providing me an opportunity to present and publish my research in the International Conference on Education in Bukittinggi. I sincerely thank Dr. Ridha Ahida, M. Hum, Dr. Asy'ari, M. Si., Dr. Novi Hendri, M. Ag, Dr. Miswardi, M. Hum, Dr. Zulfani Sesmiarni, M. Pd., H. Ramlan Nurmartias, SH, Charles, M.Pd.I. Dr. Supratman Zakir, M. Pd., M. Kom, Dr. Supriadi, M. Pd., Firdaus Anas, S. Pd., M. Kom., Melvita, S.Ag., Restika, SE., and Syamsurizal for their guidance and encouragement in carrying this project work.I also wish to express my gratitude to steering committees the officials and other staff members of the State Islamic Institute (IAIN) Bukittinggi Who rendered their help during the period of my project work..

\section{References}

[1] C. Scott, Literary translation and the rediscovery of reading. Cambridge University Press; 26 Juli 2012. pp.23

[2] C. Jones, editor. Literature, spoken language and speaking skills in second language learning. Cambridge University Press; 2019 Nov 7. pp. 56

[3] P.C. Ribeiro, B.B.de Araujo, and A. Raposo, ComFiM: a cooperative serious game to encourage the development of communicative skills between children with autism. In2014 Brazilian Symposium on Computer Games and Digital Entertainment - IEEE 2014 Nov 12. pp. 34

[4] L.S. Eng, A.R.Mohamed, and M. Javed, Analysis of students 'competency in listening comprehension of the English language at Pakistani secondary school level. Middle-East journal of scientific research. 2013;16 (3). pp.331-41.

[5] K. Aladrović Slovaček, N. Zovkić, and A.Cekovic, Language games in early school age as a precondition for the development of good communicative skills. Croatian Journal of Education: Hrvatski časopis za odgoj i obrazovanje. 2014 Feb 18;16 (Sp. Ed. 1). pp.1123.

[6] A.A.Raba, The influence of think-pair-share (TPS) on improving students' oral communication skills in EFL classrooms. Creative Education. 2017 Jan 6;8 (1). pp.12-23.

[7] R.A. Fahrutdinova, I.E. Yarmakeev, and R.R. Fakhrutdinov, The formation of students' foreign language communicative competence during the learning process of the english language through interactive learning technologies (The Study on the Basis of Kazan Federal University). English Language Teaching. 2014; 7 (12). pp.36-46. 
[8] N. Konar, English language laboratories: A comprehensive manual. PHI Learning Pvt. Ltd.; 2011 Jul 30. pp.28

[9] B. Ajisafe, and V. Okotie, Resuscitating the use of language laboratories in language teaching and learning. InThe Nigerian Academic Forum 2011 (Vol. 21, No. 1, pp. 110113).

[10]D. Allwright, Observation in the language classroom. Routledge; 2014 Sep 25. p.21

[11]A. Henderson, Richard Cauldwell, phonology for listening: Teaching the stream of speech. Birmingham: Speech in Action, 2013. pp. 332. ISBN-13: 978-0954344726. Journal of the International Phonetic Association. 2014 Aug;44 (2). pp.180-182.

[12] M. Sakai, Richard Cauldwell, A syllabus for listening: Decoding. Birmingham: Speech in Action, 2018. pp. xiii+ 240. ISBN 978-0-9543447-7-1. Journal of the International Phonetic Association.:1-5.

[13] Y. Prihartini, W. Wahyudi, A. Aliasar, M. Mukhaiyar, and A.O. Ungsi, The development of arabic learning model by using multimedia of computer at UIN STS Jambi. Al-Ta lim Journal. 2018 Jul 24;25 (2), pp.135-43.

[14] Y. Prihartini, and W. Wahyudi, The Development of Integrated Learning Model To Improve Language Skills at Arabic Language. IJER (Indonesian Journal of Educational Research). 2018 Oct 18; 3 (1). pp.9-14.

[15] W. Wahyudi, and Y. Prihartini, Development of Arabic Learning Material Based on Eclectic Method. In3rd Asian Education Symposium (AES 2018) 2019 Apr. Atlantis Press.

[16]H. Humaidi,. عدد المشكلات وظهور ها وحلولها فى تعليم اللغة العربية. Alsuna: Journal of Arabic and English Language. 2019 Nov 25; 2 (2). pp.129-49.

[17] Y.H. Wu, Effect of age on directional microphone hearing aid benefit and preference. Journal of the American Academy of Audiology. 2010 Feb 1; 21 (2). pp.78-89.

وسائل تعليم اللغة العربية لغير الناطقين بها عن طريق التكنولوجيا الحديثة. محمد علي أحمد حمزة [18) Prosiding Konfererensi Nasional Bahasa Arab. 2017; 3 (3) pp. 329-337

[19]D. A. Plesea, B. Onete, I. Maiorescu, and N. Dina, A multimedia solution for distance learning of practical skills in commodity science. In Proceedings of the 7 th International Scientific Conference 2011 Apr 1. pp. 549-552.

[20]A. Hermawan, and C. Alwasilah, Metodologi pembelajaran bahasa Arab. PT Remaja Rosdakarya; 2011. pp. 242

[21] A. P. Rovai, J.D. Baker, and M.K. Ponton, Social science research design and statistics: A practitioner's guide to research methods and IBM SPSS. Watertree Press LLC; 2013 Sep 1. pp. 67

[22]L.S. Meyers, G. Gamst, and A.J. Guarino, Applied multivariate research: Design and interpretation. Sage publications; 2016 Oct 28. pp. 4

[23]D.P. Wallace, and C.J.Van Fleet, Knowledge into Action: Research and Evaluation in Library and Information Science: Research and Evaluation in Library and Information Science. ABC-CLIO; 2012 Jun 12. pp.137

[24] J.W. Creswell, and C. N. Poth, Qualitative inquiry and research design: Choosing among five approaches. Sage publications; 2016 Dec 19.pp. 163

[25] M.I. Alhojailan, Thematic analysis: a critical review of its process and evaluation. West East Journal of Social Sciences. 2012 Oct;1 (1). pp. 39-47. 
